\title{
Overcoming constraints imposed by fiduciary duties in terms of justice as a "Leadership Challenge that Matters"
}

Author:

Prof Neil Stuart Eccles ${ }^{1}$

Affiliation:

${ }^{1}$ University of South

Africa, Pretoria

E-mail:

ecclens@unisa.ac.za

DOI:

10.15249/12-2-202

\section{Keywords:}

justice; fiduciary duty; John Rawls; Amartya Sen; Adam Smith

\section{Abstract}

This article focuses on the issue of justice as a challenge facing business and society. I advance a simple deductive argument based on two premises. The first emerges out of theories of justice and holds that fairness, as a foundational basis for justice, demands impartiality or the avoidance of bias. The second emerges out of fiduciary law and holds that the duty of loyalty owed by managers to serve the interests of investors is fundamentally partial or biased. The conclusion is the troubling fact that the fiduciary duty of loyalty owed by managers to serve the interests of investors appears to be incompatible with the demands of justice. Having presented this, I describe the impartiality tools of Rawls' veil of ignorance and Adam Smith's impartial spectator and discuss how these might be applied in this context. I speculate that while Smith's impartial spectator is absolutely incommensurable with managers' fiduciary duty of loyalty, Rawls' veil of ignorance might be used to imagine a synthesis between this duty of loyalty and the impartiality demands of justice - in theory at least. And finally, as a parting shot, I wonder whether the real "Leadership Challenge that Matters" isn't the gap between theory and reality.

\section{Introduction}

In 2017, the Albert Luthuli Centre for Responsible Leadership hosted the Fourth International Conference on Responsible Leadership under the title "Leadership Challenges that Matter" (ALCRL, 2017). The call for papers invited participants to "grapple head-on with complex and pressing challenges confronting business and society". This article represents a response to this call, focusing on the issue of justice as a 
challenge confronting business and society. The very first task then, I suppose, is to say something about why it is that a consideration of justice is relevant in relation to this conference theme. I say 'I suppose', because it seems to me that for most people this is likely to seem completely obvious, almost axiomatic. Because of this, I limit my effort in this regard to advancing two quotes in support of the importance of thinking about justice from what are arguably authoritative figures. ${ }^{1}$ The first is from Adam Smith who wrote in The Theory of Moral Sentiments (TMS) that:

Justice ... is the main pillar that upholds the whole edifice. If it is removed, the great, the immense fabric of human society, the fabric which to raise and support seems in this world, if I may say so, to have been the peculiar darling care of Nature, must in a moment crumble into atoms.

(Smith, 1759:45)

The second comes from John Rawls who somewhat provocatively wrote:

Justice is the first virtue of social institutions, as truth is of systems of thought. A theory however elegant and economical must be rejected or revised if it is untrue; likewise, laws and institutions no matter how efficient and well-arranged must be reformed or abolished if they are unjust.

(Rawls, 1971:3)

The absoluteness of this latter sentiment has of course been challenged by some (e.g. Sandel, 1998), and even Rawls (1971) himself suggested of the idea of the primacy of justice that it might have been too strongly expressed. However, it seems reasonable to assert that very few would argue against the suggestion that justice is amongst a very small handful of primary virtues of social institutions. ${ }^{2}$ It therefore stands to reason then that securing justice is surely a "Leadership Challenge that Matters".

Having 'established' this basic rationale for bothering to think about justice, let me now provide an outline of the article. The central feature is a simple deductive argument which proceeds from two premises to a conclusion. The first premise arises out of a consideration of notions of justice articulated, in the main, by two scholars, John Rawls and Amartya Sen. I develop this in the section entitled A Premise from Theories of Justice. The second premise arises out of a consideration of fiduciary law and in particular the fiduciary duty of loyalty in the context of business. I develop this in the section entitled A Premise from Fiduciary Duty. The conclusion that emerges is inevitable and probably somewhat self-evident. Nonetheless, for completeness' sake I state this, and reflect on the profound discomfort that it ought to provoke in the short section entitled The Obvious Conclusion: A Contradiction. One might be tempted at this stage to wrap things up by concluding that the contradiction that emerges is a "Leadership Challenge that Matters". However, this would almost certainly be throwing the problem out to the world at large to solve prematurely. So instead, having developed this central deductive conclusion, I then return, in the section entitled The Promise of Impartiality Devices, to the ideas advanced by Rawls and Sen in search of some hope of making progress in resolving the contradiction. As the title suggests, I compare the potential of Rawls' own proposal and Sen's Smithean proposal in terms of impartiality devices for extracting us from our uncomfortable contradiction. One of them holds some promise - at least in 
theory, that is. And finally, in the conclusion I suggest that it is in fact the gap between theoretical potential and actual likelihood that remains as the residual "Leadership Challenge that Matters" where business leadership is concerned.

\section{A premise from theories of justice}

This heading is, perhaps, somewhat overstated. There are after all countless theories or conceptions of justice. Indeed, even if one were to restrict one's attention to Western philosophy, as we are wont to do in this world dominated by the Western hegemony, there would be way too many to even begin to review here. Therefore, for the purposes of this article, I explicitly limit my attention to conceptions of justice as articulated in two important texts. The first is Rawls' 1971 book entitled A Theory of Justice which is widely acknowledged as one of the most important, if not the most important text on the subject to have emerged out of the twentieth century. The second is Sen's The Idea of Justice (Sen, 2010). This is a much more recent text and has not, and no doubt will not, have the same sort of impact as Rawls' book. Nonetheless, it is a very useful companion to Rawls's work, highlighting strengths and pointing out alternatives that might be usefully considered.

Starting then with Rawls, he set out in The Theory of Justice to formulate a conception of justice grounded in social contract theories à la Locke, Rousseau and Kant. This he hoped would stand as a superior alternative to conceptions of justice based on either utilitarianism or intuitionism which were the dominant paradigms for thinking about justice at the time. He called his conception "justice as fairness" (Rawls, 1971:11). And in the final analysis it comprised, quite simply, of Rawls' famous two principles of justice. The first principle established that:

each person is to have an equal right to the most extensive basic liberty compatible with a similar liberty for others.

(Rawls, 1971:60)

The influence of Kant's categorical imperative is clearly evident in this principle. The second principle sought to manage inevitable inequalities by declaring that:

social and economic inequalities are to be arranged so that they are both (a) reasonably expected to be to everyone's advantage, and (b) attached to positions and offices open to all.

(Rawls, 1971:60)

These, Rawls placed in a very explicit lexicological order with principle one necessarily preceding principle two. In this way, basic liberties could never be trumped by some sort of 'good of the majority' agenda.

It was not, however, just this end point of Rawls' thinking in A Theory of Justice that captured the imagination of so many subsequent philosophers. The arguments and conceptual tools that Rawls mobilised to arrive at these principles have proved to be at least as interesting. Indeed, in terms of this article, they are much more interesting and it is on some of these that I now focus. At the very outset, Rawls presented us with his 
interpretation of the common concept or role of justice. This, according to Rawls, is to deliver a set of principles and procedures that would:

provide a way of assigning rights and duties in the basic institutions of society and ... define the appropriate distribution of the benefits and burdens of social cooperation.

(Rawls, 1971:4).

According to Rawls, while conceptions of justice may vary in their formulation, this role of justice does not.

Having specified this as the role of justice, Rawls then set out to imagine the process of reasoning, grounded in what he referred to as "reflexive equilibrium" (Rawls, 1971:20), that rational people might undergo if they were tasked, in some sort of "original position" (Rawls, 1971:17), with negotiating a set of principles that would fulfil this role of justice. In other words, he sought to imagine how the social contract negotiations around principles of justice might be made to work in a manner consistent with justice as fairness. The central problem that Rawls encountered here was the influence that self-interest would inevitably bring to bear on the reasoning of the negotiators. The existence of this fundamental bias or partiality posed obvious difficulties in terms of giving expression to his foundational notion of justice as fairness. To mitigate this problem, Rawls devised his famous "veil of ignorance" (Rawls, 1971:12). It is worthwhile to quote Rawls' description of this at length:

[Behind the veil of ignorance] no one knows his place in society, his class position or social status, nor does any one know his fortune in the distribution of natural assets and abilities, his intelligence, strength, and the like. I shall even assume that the parties do not know their conceptions of the good or their special psychological propensities.

(Rawls, 1971:12)

In short, rather than trying to imagine away self-interest, Rawls imagined imposing stringent limitations on self-awareness so as to prevent self-interest from scuppering any hope that self-interested people might come to some sort of agreement on principles of justice grounded in fairness.

These notions of the foundational nature of fairness as a basis for justice and the centrality of impartiality in thinking about justice are as good a prompt as any to switch our attention from Rawls to Sen. They are after all, arguably the most important points of convergence between the two. But before I deal with convergence, let me first dispense with the major divergence. Sen argued that conceptions of justice that have emerged since the beginning of the enlightenment can be broadly divided into two branches. The first he called "transcendental institutionalism" (Sen, 2010:5) and it is into this branch that he placed Rawls' approach. The branch is characterised by two features. The first is that the participants are concerned with trying to develop prefect conceptions of justice or conceptions that are, according to Sen, transcendental in character. ${ }^{3}$ Hardly surprisingly then, the second feature of transcendental institutionalists is their specific focus on institutions of society, rather than the nitty-gritty of actual societies. Besides Rawls, Sen traced the pedigree of this branch from Hobbes, through Locke, Rousseau 
and Kant. It is important to note that vastly different conceptions of justice would fall within this branch. For example, in terms of twentieth-century philosophers, besides placing Rawls into this branch, he also placed Nozick there.

The second branch of thought Sen called "realization-focused comparison" (Sen, 2010:7) and it is into this branch that he placed his own ideas. Participants in this branch, so Sen argued, accept the likelihood that perfect conceptions of justice probably don't exist, or if they do exist are unimaginable let alone attainable by mere mortals. However, while perfection is likely to be unattainable, we are, Sen argued, most certainly capable of comparing alternative actual arrangements (realisations) and judging the merits of them with a view to choosing the best or most just. In the list of philosophers who have historically pursued this path, Sen named Smith, de Condorcet, Bentham, John Stuart Mill, Wollestonecraft, and Marx. ${ }^{4}$ This is an essentially pragmatist approach. Interestingly, Rawls did not deny the importance of this type of pragmatism. In his discussion on the subject or role of justice he drew a distinction between what he called "strict compliance" and "partial compliance theory" (Rawls, 1971:8). Rawls' strict compliance refers to the pursuit of, or at least contemplation of, a perfectly just society akin to what Sen referred to as the "transcendental" approach. In contrast, his partial compliance theory dealt with the principles and practices with which we tackle "the things that we are faced with in everyday life" (Rawls, 1971:9). Rawls gladly acknowledged the "pressing and urgent" (Rawls, 1971:9) character of these everyday life issues but argued that without some sort of ideal or transcendental theory of perfect justice, we would be unable to achieve a "systematic grasp of these more pressing problems" (Rawls, 1971:9). This sentiment was partially echoed by Kamm (2011) in her critical review of Sen's position on justice and it was screamed by Valentini (2010) in her strong critique of Sen.

While there is, of course, a great deal of intuitive appeal to this criticism of Sen's pragmatism, some caution is perhaps necessary. To illustrate why I say this, a return to the points of convergence between the ideas of Rawls and Sen is called for. This return is convenient for the flow of my own argument too. By way of reminder, these points of convergence lay in: (a) the foundational or prior nature of fairness as a condition for justice to exist; and (b) the centrality of impartiality or the absence of bias to thinking about justice or formulating ideas about justice. In a very real sense, it could easily be argued that these represent essentially transcendental foundations of justice in Sen's conception of justice. They are foundational ideas from which we might well be able to embark on a pursuit of some "systematic grasp of these more pressing problems" that Rawls calls for. So, in much the same way as Rawls did not deny the need for pragmatism, it seems fair to acknowledge that Sen's realisation-focused comparisons are, to some extent, grounded in an essentially transcendental foundation of justice as fairness. He elaborated on this as follows:

I argue that we have good reason to be persuaded by Rawls that the pursuit of justice has to be linked to - and in some sense derived from - the idea of fairness ... So what is fairness? This foundational idea can be given shape in various ways, but central to it must be the demand to avoid bias in our evaluations, taking note of the interests and 
concerns of others as well, and in particular the need to avoid being influenced by our respective vested interests, or by our personal priorities or eccentricities or prejudices.

(Sen, 2010:54)

My aim in this section was, of course, not primarily to enter into the discussion of the relative strengths and weaknesses of Rawls' and Sen's conceptions of justice. Rather, it was to extract a premise from their theories of justice. And it is this convergence between Rawls and Sen which holds that fairness, as a foundational basis for justice, demands impartiality or the avoidance of bias that is the premise that I advance.

\section{A premise from fiduciary duty}

So far so good. We can now turn our attention to developing the second premise of the argument through a consideration of fiduciary law and in particular fiduciary duties. At the outset it is perhaps prudent to acknowledge that "[f]iduciary law is messy" (Smith, 2002:1400) and that, as was the case with theories of justice, a comprehensive review of this messiness is beyond the scope of this short article. Nonetheless, a brief build-up is required. Fiduciary law has its immediate origins in trust law (Brudney, 1997) which can in turn be traced to one of at least three earlier traditions which all sought to provide equitable responses to rigid positive law: the Roman Fideicommissum, the Germanic Salmannus, and the Islamic Waqf (Avini, 1995-1996). It is not, however, these contested early origins of fiduciary law that are really the source of the messiness of fiduciary law, but rather its grounding in Equity according to DeMott (1988). The utility of this grounding in Equity, and in particular its flexibility (as opposed to the rigidity of positive law), has resulted in its application in a bewildering array of contexts (Easterbrook \& Fischel, 1993; Brudney, 1997; Smith, 2002). Besides formal trust relationships which are arguably more of a metaphor for fiduciary relationships than an actual instance (see DeMott, 1988), fiduciary duty has been used in relation to guardian/ward relationships, attorney/client relationships, and even counselling relationships. In the world of business, the focus of this article, the ideas of fiduciary duty have been applied with significant zeal to management/investor relationships. Fairly closely allied to this is the context of investment where investment adviser/client relationships and pension trustee/ beneficiary relationships in particular, have been equally zealously interpreted as falling under the umbrella of fiduciary law.

This diversity of application poses the challenge to scholars in the field of presenting theories of fiduciary duty that are: on the one hand adequately discerning, allowing for the appropriate distinction to be drawn between relationships where fiduciary duties ought to apply and those where other forms of relationship exist; and on the other hand appropriately flexible, accommodating this diverse array of relationships that have already been judged to fall under the banner. Inevitably, a number of theories have been advanced. Easterbrook and Fischel (1993), for example, have suggested that fiduciary law is in fact nothing more than an extension of contract law aimed at mitigating against the inevitable incompleteness of contracts, with no special moral underpinnings. They stated that: 
Fiduciary duties are not special duties; they have no moral footing; they are the same sort of obligations, derived and enforced in the same way as other contractual undertakings.

(Easterbrook et al., 1993:427)

However, most scholars seem to have held to the opposite view - viz. that fiduciary duties are not simply an extension of contract law. Smith (2002) provided a brief overview of the various manifestations of these which include: Frankel's delegation of power theory; Sealy's four categories of fiduciary duty based on empirical categorisation of actual cases; Scott's theory based on acting in the interests of another; Shepherd's collage of power and best interests; and Rock and Wachter's interpretation based on property rights, norm governance and the removal of opportunism. Smith's own contribution, which he dubbed the critical resources theory, holds that:

fiduciary relationships form when one party (the fiduciary) acts on behalf of another party (the beneficiary) while exercising discretion with respect to a critical resource belonging to the beneficiary.

(Smith, 2002:1402, emphasis in original)

The final perspective worth noting is DeMott's (1988) which arguably lies somewhere in between the Easterbrook et al.'s contract extension position and the more conventional position. She did not hold that fiduciary duty is no more than an extension of contract law. However, her pragmatist interpretation of fiduciary duty as a mechanism, rooted in Equity, allowing flexibility of application to a myriad of situations when other formalised arrangements fail is not dissimilar to Easterbrook et al.'s (1993) explanation of fiduciary duty as a mechanism that kicks in when formal contracts fail because they are incomplete.

This theoretical and application messiness aside, there is at least one absolutely consistent feature of fiduciary duty and this is the duty of loyalty. ${ }^{5}$ The 'strength' of this duty of loyalty may vary from situation to situation (Easterbrook et al., 1993), and the presence of a duty of loyalty is not, in and of itself, sufficient to ensure that a fiduciary relationship exists. However, there is always a duty of loyalty present. Broadly speaking, this entails the prioritisation by the fiduciary of the interests of the beneficiary in relation to the activities falling under the fiduciary relationship. As DeMott (1988) put it:

If a person in a particular relationship with another is subject to a fiduciary obligation, that person (the fiduciary) must be loyal to the interests of the other person (the beneficiary). The fiduciary's duties go beyond mere fairness and honesty; they oblige him to act to further the beneficiary's best interests.

(DeMott, 1988:882)

Most often, discussions surrounding this duty of loyalty have focused on the interests of the fiduciaries and beneficiaries only (e.g. Smith, 2002). And the point of the duty of loyalty then is to ensure that fairness prevails in terms of the activities associated with the relationship between these two parties and that the fiduciaries do not exploit their positions for their own gain at the expense of the beneficiaries. This is, if you like, the explicit or overt perspective. There is, however, a somewhat more implicit perspective. As I have noted previously, to be completely exhaustive in considering this duty of loyalty, one in fact needs to contemplate the interests of three participants or groups 
of participants (Eccles, 2018). There are the beneficiaries and the fiduciaries, but there are also those outside of the fiduciary relationship. When this more complete web of relationships is considered, there seems no reason why the fiduciary duty of loyalty and the principle of exclusive benefit would not insist on the prioritisation of the interests of the beneficiary over both the interests of the fiduciary and anyone else outside of the fiduciary relationship.

Of course, in this article the focus is specifically on the context of business. And it is towards this that I now turn my attention. Within this context there are two reasonably uncontested features of the duty of loyalty that I would like to dispense with at the outset. The first is that the fiduciary duty of loyalty is typically considered to be strong in this context (Easterbrook et al., 1993). The second is that the fiduciaries in the relationship are unambiguously management. However, some fairly notable ambiguity oozes into the story when we begin to think about: (a) who the beneficiaries are; and (b) what their interests might be. Without a doubt, the prevailing view remains grounded in shareholder theories of management championed powerfully by the likes of Milton Friedman (e.g. Friedman, 1970). This holds that the sole beneficiaries of the fiduciary duty of loyalty of managers are the shareholders as the owners of the business, and that their interests are served by maximising the risk-adjusted financial returns on their investment i.e. delivering maximum shareholder value. This is the 'business of business' sort of notion. And if anyone is in any doubt that this is the prevailing paradigm in practice, then they might have a look at managerial remuneration practices and in particular the almost ubiquitous share option schemes which clearly seek to align the interests of managers with those of shareholder.

The notion that the interests of beneficiaries (and therefore the duty of managers) lie purely in maximising shareholder value has, however, come under some scrutiny (Smith, 1999; Hawley \& Williams, 2007). Smith (1999), drew attention to the fact that if one were to assume the widespread application of modern portfolio theory when contemplating shareholders, one would have to assume that shareholders are likely to have exposure to a company beyond simply equity investments. In particular, portfolio diversification would mean that they are likely to have exposure to debt investments too. In other words they would have interests beyond just those of shareholders. Assuming that borrower/ lender relationships do indeed fall under the banner of fiduciary relationships, ${ }^{6}$ then, according to Smith (1999), managers as fiduciaries cannot assume that their duty of loyalty is solely to shareholders or that the interests of the beneficiaries are served by maximising shareholder value alone. Shareholder value might be contrary to the interests of debt financiers.

Hawley and Williams took this basic sentiment much further with their theories of fiduciary capitalism (Hawley \& Williams, 2000a ${ }^{7}$ ) and universal ownership (Hawley \& Williams, 2000b). Both of these theories arose from the recognition that increasingly the market is owned by large institutional investment schemes such as pension funds, mutual funds or sovereign wealth funds which are collective in character. Besides emphasising the fiduciary role of the managers and trustees of these collective schemes 
to the actual investors, their theory of fiduciary capitalism emphasised the fact that it might be necessary to think about dismantling traditional archetypes of investors as the savings of more and more members of society get pooled into these massive investment schemes. The insinuation is that the interests of beneficiaries of the fiduciary relationships are likely to extend way beyond the capitalist fetish of simply maximising risk-adjusted financial returns on their investment. Their second theory, that of universal ownership, was premised on the fact that because of the size of these collective investment funds, and under the "guidance" of modern portfolio theory, their portfolios tend to be highly diversified. The effect of this is that one might imagine that they own not just an array of asset classes in selected companies, but rather a piece of the "entire market" (Hawley \& Williams, 2007:416). Because some of the externalities of individual businesses become internalised at the level of the entire market, this has potentially massive implications in terms of how managers might give expression to their duties of loyalty towards investors. Externalities which might be highly beneficial to investors in one particular company, might be detrimental to the market as a whole and therefore not in the interests of universal owners.

In short, Hawley and Williams' two theories significantly expanded the understanding of who the beneficiaries of the business manager/investor fiduciary relationship might be, and potentially how their interests might be served. However, in spite of this opening ${ }^{8}$ up of the manager/investor fiduciary universe, we are nonetheless still left with the three groups of participants when thinking about the duty of loyalty in the context of business: the beneficiaries, the fiduciaries, and those outside of the fiduciary relationship. The opening up that Hawley and Williams imagined has most definitely not completely done away with those outside the fiduciary relationship. Hawley (2015) himself acknowledged this in relation to fiduciary capitalism by noting that this is not the same as "citizen's capitalism" as imagined by Davis, Lukumnik and Pitt-Watson where everyone is a beneficiary. This Hawley described as "more of a potentiality than a completed actuality" (Hawley, 2015:22). And, as I have already argued in a previous article, if one is looking for empirical evidence to support this, it is reasonably safe to assume that the interests of the roughly 750 million people who, according to the World Bank (2016) live on less than $\$ 1.90$ per day, will never be meaningfully represented by business manager fiduciaries (Eccles, 2018).

Much the same can be said of the "universal" in Hawley and Williams' (2000a) universal ownership. While portfolio diversification is indeed something that is pursued, the idea that this is approaching 'universal' is almost certainly also "more of a potentiality than a completed actuality" (Hawley, 2015:22). Even the largest portfolios will be biased along at least two lines. Firstly, they will typically be geographically biased, focusing their attention on activities in either their own 'home market' or the largest sovereign markets in the world mainly in developed countries. Secondly, they will typically be biased in favour of large publicly listed companies. After all, the great merit of collective investments is that they allow the accumulation of sufficient capital to allow vast enterprises with massive power to be established. And so while it may well be that the fiduciary duty of loyalty 
demands of managers more than simply the maximisation of risk-adjusted financial return, at best this means that they ought to consider the maximisation of risk-adjusted financial returns of portfolios that are inherently biased in favour of big countries and big companies. And, of course, it is necessary to recognise that what might be good for the market might not in all instances be good for society at large.

All of this brings me to the ultimate point of this section - to a premise from fiduciary duty. This is that, in spite of all of these 'extensions' to how we might think about fiduciary duty in the context of business managers, the basic character of the managerial fiduciary duty remains remarkably unaltered. It holds that managers still owe a strong duty of loyalty to investors (whoever they may be) and this implies an exclusive focus on pursuing their best interests specifically (whatever these may be). Ultimately, this fiduciary duty of loyalty owed by managers to serve the interests of investors is thus fundamentally partial or biased.

\section{The obvious conclusion: a contradiction}

For those of you who have been paying careful attention during this journey through the conceptual landscapes of the theories of justice of Rawls and Sen and of fiduciary duty, a fundamental contradiction should now be apparent. But in case I have lost you in all of the rambling, let me explicitly articulate this in the form of the simple argument I promised in the introduction:

Premise 1: From the theories of justice of Rawls and Sen, it emerges that fairness, as a foundational basis for justice, demands impartiality or the avoidance of bias.

Premise 2: From a brief survey of fiduciary law it is apparent that the duty of loyalty owed by managers to serve the interests of investors is fundamentally partial or biased.

The obvious conclusion: The fiduciary duty of loyalty owed by managers to serve the interests of investors seems likely to be incompatible with the demands of justice.

At this point it is perhaps worthwhile to think for a moment about the implications of this conclusion in terms of the 'real world' rather than in the purely abstract theoretical realm where this article is generally located. Some might wonder how this finding relates to actual problems confronting business? The conventional response to the task of answering such a question would, of course, be to try and apply this theoretical finding to one or other of a myriad of cases of business ethics failures (e.g. Enron, Volkwagen, KPMG in South Africa etc). This would, of course, not work here. This is because the challenge unearthed is not a problem associated with acute acts of either imprudence or malfeasance on the part of fiduciaries leading to catastrophic corporate failures. ${ }^{9}$ In fact, such problems would inevitably be deemed as failures of fiduciary duty since they would lead to destruction of value for the beneficiaries of fiduciary trust. The challenge here is 
far more fundamental or essential than this. If you like, the challenge here is chronic in character, and emergent out of the very essence of how business is constructed.

In short then, if we accept that justice is amongst a very small handful of primary virtues of social institutions, and given the powerful leadership roles that business managers occupy in today's social institutions, we must then accept that this conclusion, in and of itself, constitutes a grave leadership challenge, and one that certainly matters. As I mentioned in the introduction, one might be tempted at this stage to say: 'A problem shared is a problem solved. So job done!' However, one feels a certain pressure to contemplate solutions. To do this, I return to the works of Rawls and Sen, and in particular the impartiality devices that they advocated in the hope that these might hold some solution.

\section{The promise of impartiality}

So, justice is an important virtue in social institutions and we therefore assume that we ought to expect leaders (in general and specifically in the powerful institution of business) to act in a just way. Or, to borrow from Sen's realisation-focused comparison approach, we ideally want them to take decisions that would lead to realisations that would be judged as fair if they were to be subjected to something like impartial comparisons. To do this, as we have seen, would require them, amongst other things, to take decisions on the basis of impartiality. The question is how might this be brought about, and in particular, how might this be brought about in the context of fiduciary law that demands loyalty to investor interests?

Both Rawls and Sen proposed impartiality devices. As I have already described, Rawls developed his veil of ignorance, in which, rather than trying to imagine away self-interest, Rawls imagined imposing stringent limitations on self-awareness. In effect, people behind Rawls' veil of ignorance would not know either their position in society, or their natural talents. They would not know whether they were a genius born into wealthy family, or a fool born into a poor one. Or a fool born into a wealthy family or a genius born into a poor one. They would not know whether they were male or female, black or white, homosexual or heterosexual, Christian or Muslim ... And from the position of this limited self-awareness, they would, according to Rawls, be able to reflect fairly on matters pertaining to justice. ${ }^{10}$

In contrast to this, Sen (2010) advocated the use of Adam Smith's impartial spectator. This is arguably a much more complicated construct and requires some elaboration before we examine Sen's interpretation specifically. The idea of the impartial spectator emerged out of Smith's TMS. In this, Smith argued that moral reasoning is grounded in our capacity for fellow-feeling or "sympathy". ${ }^{11}$ This fellow-feeling arises, not out of our actual ability to feel what others are feeling which is obviously empirically impossible, but rather out of our ability to imagine what we might feel were we to find ourselves in their shoes. The idea of the spectator then emerged gradually in TMS. Early references to the spectator 
were, by and large, descriptions of real spectators - external parties who observe social occurrences and with whom the passions of the persons immediately involved may be more or less aligned through the action of sympathy. And as Smith stated:

When the original passions of the person principally concerned are in perfect concord with the sympathetic emotions of the spectator, they necessarily appear to this last just and proper, and suitable to their objects.

(Smith, 1759:10)

In this way, when we find ourselves in the role of the spectator, we have the basis for judging the passions of others through sympathy. And not surprisingly, Smith then spent significant time discussing how biases may be inherent in the sentiments of both the persons immediately involved and in the spectators. However, as Smith's argument evolved, so too did the nature of the spectator. At first, Smith contemplated the universalising of the impartial spectator in a manner somewhat anticipatory of Kant's first formulation of the categorical imperative. He wrote:

But these, as well as all the other passions of human nature, seem proper and are approved of, when the heart of every impartial spectator entirely sympathizes with them, when every indifferent by-stander entirely enters into, and goes along with them.

(Smith, 1759:37)

And, by the time Smith got to Part III of TMS, the impartial spectator was in general no longer a real spectator, but rather the ideal spectator within each of us which we use to evaluate our own sentiments and actions (Young, 2007). Thus Smith wrote:

We suppose ourselves the spectators of our own behaviour, and endeavour to imagine what effect it would, in this light, produce upon us. This is the only looking-glass by which we can, in some measure, with the eyes of other people, scrutinize the propriety of our own conduct.

(Smith, 1759:60)

At this point a certain sensitivity to the moral jeopardy associated with relativism enters into Smith's conception of the impartial spectator. He used a metaphor of a large landscape seen through the window of the small room in which he was writing. From the position of his desk this vast landscape seemed insignificant relative to the room. To gain perspective, Smith noted, one must step outside and view both spaces from an equal distance. The same applies when one is considering human behaviour. Thus he wrote:

In the same manner, to the selfish and original passions of human nature, the loss or gain of a very small interest of our own, appears to be of vastly more importance, excites a much more passionate joy or sorry, a much more ardent desire of aversion, than the greatest concern of another with whom we have no particular connexion. His interests, as long as they are surveyed from this station, can never be put into the balance with our own, how ruinous soever to him. Before we can make any proper comparison of those opposite interests, we must change our position. We must view them, neither from our own place nor yet from his, neither with our own eyes nor yet with his, but from the place and with the eyes of a third person, who has no particular connexion with either, and who judges with impartiality between us.

(Smith, 1759:70) 
It is at around this point that Sen really grabbed a hold of Smith's ideas to further his own arguments on open and closed impartiality in terms of justice (Sen, 2002, 2010). Sen was particularly captivated by Smith's suggestion that the greater the distance the spectator is from the actual moral matter being considered, the more impartial the evaluation or thinking is likely to be. For instance, Smith wrote:

The propriety of our moral sentiments is never so apt to be corrupted, as when the indulgent and partial spectator is at hand, while the indifferent and impartial one is at a great distance.

(Smith, 1759:79)

It is this demand for greater distance that formed the basis for Sen's criticism of Rawls' veil of ignorance as an impartiality device. Sen argued that while Smith's impartial spectator seems to explicitly call for scrutiny from a distance and thereby mitigates against parochialism, Rawls' veil is imagined to be applied in the specific context of social contract negotiations within the sovereign state or polity. Sen referred to his interpretation of Smith's approach to impartiality as an example of open impartiality and to Rawls' approach as an example of closed impartiality.

There are, however, some serious difficulties with Sen's comparative interpretation of Smith's impartial spectator and Rawls' veil of ignorance as impartiality devices in my view. In particular, the distinction between these two impartiality devices does not rest comfortably on the openness of the impartial spectator and the closed-ness of the veil of ignorance. From the side of the veil of ignorance, while its application by Rawls in his The Theory of Justice was indeed somewhat closed as described by Sen, this parochial character need not necessarily be the case at all. It is not at all difficult to imagine the veil of ignorance being applied to a more global consideration of justice. We might very simply, for example, imagine adding to the list of ignorances which were presented above, that people behind the veil of ignorance would not know whether they were living in Norway with Human Development Index (HDI) in 2014 of 0.944 or in Niger with an HDI in 2014 of 0.348 (UNDP, 2015). And, as Sen himself acknowledged, this is precisely the challenge that Rawlsean scholars such as Pogge have taken up. In effect, Sen confused the specific application of the veil of ignorance by Rawls with the potential inherent in the device. The veil of ignorance can be used in as open or as closed a fashion as we choose to imagine it being used. And in spite of Sen's suggestion to the contrary, Smith's impartial spectator is at least as open to ambiguity in terms of its open- or closed-ness as Rawls' veil of ignorance is. Smith's invocation of various manifestations of impartial spectators through the passage of TMS is bewildering, to say the least, and it is little surprise that some authors have concluded that his impartial spectator is actually unsatisfactorily closed in character (e.g. Shin, 2015).

In short, contrary to Sen's attempt to box Rawls' veil of ignorance as a closed impartiality device, and Smith's impartial spectator as an open impartiality device, either of these devices can be more or less open or closed depending on whether they are interpreted as such. ${ }^{12}$ However, if Sen was indeed incorrect in terms of the distinction between the veil of ignorance and the impartial spectator, this then begs the question, what is the 
difference? It is Rawls himself who provided at least one answer to this. In a comparison between the elements of the impartial spectator with those of the veil of ignorance he stated:

In the original position [i.e. behind the veil of ignorance], by contrast [to the impartial spectator], the parties are mutually disinterested rather than sympathetic; but lacking knowledge of their natural assets or social situation, they are forced to view their arrangements in a general way.

(Rawls, 1971:187)

It is the notion of interests that is crucial. Under the veil of ignorance, the contemplator of justice (for want of a better phrase) is imagined to be explicitly self-interested in the outcome of the decision and disinterested in the outcome in terms of other parties. In other words, the contemplator is explicitly concerned with seeing his or her own interests advanced. They just aren't quite sure who they actually are and it is through this informational limitation that the impact of bias is limited and impartiality secured. In the case of the ideal impartial spectator on the other hand we seek to reason away self-interest through sympathy. Using sympathy we try to imagine what someone would see in our actions if they had no particular interest in them or the outcome of them, or as Rawls put it "where his own interests are not at stake" (Rawls, 1971:186). In this case, rather than mutual disinterest, the ideal is almost a sense of complete disinterest.

This distinction is vitally important when it comes to considering the promise inherent in these two impartiality devices in terms of resolving the apparent contradiction between the impartiality demands of justice and the inherent bias of the fiduciary duty of loyalty in the context of business. But before considering the implications of this it is first necessary to imagine the application of both of these devices in the context of day-to-day pragmatic realisation-focused comparisons that Sen advocated. ${ }^{13}$ It is in this day-to-day context that business leaders make their decisions under the constraints of their fiduciary duty of loyalty to investors, and it is thus in this context that we are interested in this article. To give expression to the demands of justice as fairness in this context, under the impartial spectator device, managers would in effect be called upon to simply step away from their parochial focus on the interests of investors in their decision making, and sympathise impartially with the sentiments of a business' stakeholders in the most open sense imaginable. They would be called on to imagine what sentiments their decisions might provoke in society at large and to act in a manner which would not give particular preference to any particular individual or group. Because the interests of the investors would no longer be primary, this arrangement would be in absolute conflict with the fiduciary duty of loyalty. In short, the impartial spectator and the duty of loyalty are technically incommensurable.

In contrast, placing managers behind the veil of ignorance would not demand that they abandon their focus on the interests of the beneficiaries of their fiduciary duty. It would simply place extreme constraints on the information that a fiduciary would have in terms of who the beneficiary of their duty of loyalty might be. ${ }^{14}$ And through this, the day-to-day decisions of managers would necessarily approach impartiality. In theory at 
least then, it seems that while Smith's impartial spectator is doomed in the face of the fiduciary duty of loyalty, the veil of ignorance could present a mechanism by which the contradiction between the impartiality demands of justice and the duty of loyalty might be somewhat miraculously resolved.

\section{Conclusion: really}

Which brings me to the conclusion of this article. To recap, what I have done is to trace a simple deductive argument which concludes with the uncomfortable possibility that the fiduciary duty of loyalty owed by managers to serve the interests of investors appears to be incompatible with the demands of justice. While simply presenting this might well have been sufficient in terms of the theme of "Leadership Challenges that Matter" there is something unsatisfactory about not even attempting to contemplate solutions. And so, from this contradiction, I embarked on an exploration of the impartiality devices proposed by Rawls and Sen in search of a solution. And lo and behold, while Smith's impartial spectator advocated by Sen doesn't seem to hold much promise in terms of engineering a synthesis, Rawls' veil of ignorance certainly does - at least in theory that is. The fact that the veil of ignorance does not call for participants to relinquish selfinterest means that it is not immediately incompatible with fiduciary duties of loyalty which insist that such interests are pursued exclusively. Which is all just peachy, really at least in theory that is. The repetition of this sentiment is intentional. The key question that we ought perhaps to be left with from this article is whether there is any hope whatsoever that something akin to a veil of ignorance might be brought to bear in the context of the day-to-day decision making of business leaders? Of course, a conclusion is obviously not the place to attempt to answer a new question. And so I leave it hanging except for a final quote from Rawls which I think captures the real "Leadership Challenge that Matters":

Suppose that we transpose people from a society in which property, in good part as a result of fortune and luck, is very unequal into a well-ordered society regulated by the two principles of justice. There is no guarantee that all will gain by the change if they judge matters by their previous attitudes. Those owning large properties may have lost greatly and historically they have resisted such changes. (Rawls, 2005:17)

\section{Acknowledgements}

This research was funded in part by an NRF Incentive Funding for Rated Researchers grant.

\section{References}

ALCRL (Albert Luthuli Centre for Responsible Leadership). (2017). Fourth International Conference on Responsible Leadership: Leadership Challenges That Matter. http://www.up.ac.za/media/shared/213/ZP_ Files/2016/2017-alcrl-4th_int_conf_rl_announcement.zp84866.pdf [Accessed 31 January 2017].

Avini, A. (1995/1996). The origins of the modern English trust revisited. Tulane Law Review, 70:1139-1163. 
Brudney, V. (1997). Contract and fiduciary duty in corporate law. Boston College Law Review, XXXVIII(4):595-665.

Buchanan, A.E. (1982). Marx and Justice. The Radical Critique of Liberalism. London: Methuen.

DeMott, A. (1988). Beyond metaphor: An analysis of fiduciary obligation. Duke Law Journal, 1988(5):879-924. https://doi.org/10.2307/1372643

Easterbrook, F.H. \& Fischel, D.R. (1993). Contract and fiduciary duty. Journal of Law \& Economics, XXXVI: 425-446. https://doi.org/10.1086/467282

Eccles, N.S. (2018). Remarks on Lydenberg's "Reason, Rationality and Fiduciary Duty”. Journal of Business Ethics, 151(1):55-68. https://doi.org/10.1007/s10551-016-3254-z

Friedman, M. (1970). The social responsibility of business is to increase its profits. The New York Times Magazine, 13 September.

Hawley, J.P. (2015). Towards a fiduciary capitalism perspective on business ethics. In: W. Sun, C. Louche \& R. Pérez (eds.). Finance and Sustainability: Towards a New Paradigm: A Post-Crisis Agenda. Bingley: Emerald Group. 19-37.

Hawley, J.P., Johnson, K. \& Waitzer, E. (2011). Reclaiming fiduciary duty balance. Rotman International Journal of Pension Management, 4(2):4-14.

Hawley, J.P. \& Williams, A.T. (2000a). The Rise of Fiduciary Capitalism. Philadelphia, P.A.: University of Pennsylvania Press.

Hawley, J.P. \& Williams, A.T. (2000b). The emergence of universal owners. Challenge, 43(4):43-61. https://doi.org/ $10.1080 / 05775132.2000 .11472161$

Hawley, J.P. \& Williams, A.T. (2007). Universal Owners: challenges and opportunities. Corporate Governance: An International Review, 15(3):415-420. https://doi.org/10.1111/j.1467-8683.2007.00574.x

Kamm, F.M. (2011). Sen on justice and rights: A review essay. Philosophy \& Public Affairs, 31(1):82-104. https://doi.org/10.1111/j.1088-4963.2011.01199.x

Marx, K. (1990). Capital Volume 1. London: Penguin Classics.

Rawls, J. (1971). A Theory of Justice. Cambridge, U.S.A.: Harvard University Press.

Rawls, J. (2005). Political Liberalism. New York: Columbia University Press.

Sandel, M.J. (1998). Liberalism and the Limits of Justice. Cambridge, U.K.: Cambridge University Press. https://doi.org/10.1017/CBO9780511810152

Sen, A. (2002). Open and closed impartiality. Journal of Philosophy, 99(9):445-469. https://doi.org/10.2307/ 3655683

Sen, A. (2010). The Idea of Justice. London: Penguin.

Shin, J.M. (2015). Adam Smith's impartial spectator: His reliance on societal values, limits in inspiring altruism and application in today's context. Vanderbilt Undergraduate Research Journal, 10:1-10. https://doi.org/10.1 5695/vurj.v10i0.4016

Smith, A. (1759). The Theory of Moral Sentiments. Pantianos Classics. 15. https://doi.org/10.1093/oseo/ instance.00042831

Smith, D.G. (2002). The critical resource theory of fiduciary duty. Vanderbilt Law Review, 551:1399-1497. https://doi.org/10.2139/ssrn.339100

Smith, T.A. (1999). The efficient norm for corporate law: A neotraditional interpretation of fiduciary duty. Michigan Law Review, 98(1):214-268. https://doi.org/10.2307/1290199

UNDP. (2015). Human Development Report 2015. UNDP. http://hdr.undp.org/sites/default/files/2015_human_ development_report.pdf [Accessed 31 January 2018].

Valentini, L. (2010). A paradigm shift in theorizing about justice? A critique of Sen. CSSJ Working Papers Series. Oxford: University of Oxford.

World Bank. (2016). Development Goals in an Era of Demographic Change. Washington, U.S.A.: World Bank.

Young, J.T. (1992). Natural morality and the ideal impartial spectator in Adam Smith. International Journal of Social Economics, 19(10/11/12):71-82. 


\section{Endnotes}

1. One might add to this the fact that at the time of drafting this article, the World Economic Forum, the self-appointed forum for the world's leaders, was meeting in Davos in their annual pantomime of power and wealth. At this meeting, a very prominent (and distinctly ironic) theme was the concern regarding economic inequality which is nothing if not a concern about justice.

2. One noteworthy exception here might be Marxists who have argued that the consideration of justice is only relevant in contexts which are, by definition, unjust. For a detailed discussion of this radical position see Buchanan (1982).

3. Valentini (2010) has criticised Sen's use of the word 'transcendental' and suggested that he might have done better using the term 'categorical'.

4. Marx would no doubt be absolutely horrified that his name might be used in the same breath as Bentham who he described as: "a genius in the way of bourgeois stupidity" (Marx, 1990, footnote 51:758-759), or John Stuart Mill who he described as: "On a level plain, simple mounds look like hills; and the insipid flatness of our present bourgeoisie is to be measured by the altitude of its 'great intellects"” (Marx, 1990:654).

5. The duty of care is a close second.

6. It is important to note that this is most definitely not universally accepted (see Brudney, 1997). Many would hold that the interests of debt financiers are more rigidly protected by strict contractual arrangements.

7. Besides Hawley and Williams' own work on this subject, a special issue of the journal Corporate Governance: An International Review, 15(3) of 2007 is an important source.

8. To borrow the terminology of open and closed that Sen (2010) uses in relation to impartiality.

9. The "some-bad-apples-theory" as articulated in the call for papers for the 2018 European Business Ethics Network Research Conference. http://www.eben-net.org/?q=content/callpapers-eben-research-conference-2018 [Accessed 24 April 2018].

10. Rawls was of course most concerned with their ability to participate fairly in negotiating principles of justice in original social contract negotiations in a particular sovereign state or polity.

11. Smith emphasised the fact that, while sympathy is typically thought of as more akin to pity or the sharing of negative feelings, his view was that it might just as appropriately be applied to "denote our fellow-feeling with any passion whatever" (Smith, 1759:7).

12. The usefulness of Sen's discussion of open and closed impartiality in the present context should not, however, be completely overlooked. After all, Hawley and Williams' notion of fiduciary capitalism emphasises the duty of impartiality of a fiduciary to all of his or her beneficiaries (Hawley et al., 2011). This is a perfect example of closed impartiality and Sen's critique of closed impartiality as a device for ensuring that justice prevails in effect captures the essence of the contradiction discussed in this article.

13. This is obviously more unorthodox in the case of Rawls' veil of ignorance, which is typically associated with the formulation of transcendental principles.

14. One must acknowledge that some of the informational constraints would be rather difficult to imagine. For example, I argued earlier that one of the limitations of Hawley and Williams' (2000b) fiduciary capitalism was that a huge number of people are simply not investors and 
are therefore not represented by business manager fiduciaries. For the veil of ignorance to work, the information constraint would have to include that the fiduciary would not know whether the beneficiary was in fact a beneficiary. This poses an interesting logical conundrum.

15. No city stated. 